\title{
The Chávez Era Perspective for an Innovative Cultural Policy
}

\author{
Pablo Victor Fontes* \\ Mônica Leite Lessa**
}

\begin{abstract}
This paper examines Venezuela's audio-visual sector and its cultural and media policies during the Chávez Era (1999-2013). Accordingly, this analysis essentially emphasises how Chávez's perception of the absence of representation concerning Venezuelan popular culture served as the basis for proposing a remodelling of cultural and media policies. Bearing in mind this scenario, we point out that this initiative took place in order to rescue, promote and appreciate national distinctiveness and to stimulate the population's inclusion and social development. In this sense, we indicate that the reconstitution of Venezuela's social fabric took place through a new, important and original agenda of cultural and/or audio-visual goods. Also, we suggest that, to a certain extent, the same process took place in Latin America.
\end{abstract}

Keywords: Venezuela; culture; media; Hugo Chávez; globalisation.

\section{Introduction}

This paper examines Venezuela's audio-visual sector and its cultural and media policies during the Chávez Era (1999-2013). Accordingly, this analysis essentially emphasises how Chávez's perception of the absence of representation concerning Venezuelan popular culture served as the basis for proposing a remodelling of cultural and media policies. Bearing in mind this scenario, we point out that this initiative took place in order to rescue, promote and appreciate the national distinctiveness and to stimulate the population's inclusion and social development. In this sense, we indicate that the reconstitution of Venezuela's social fabric took place through a new, important and original agenda of cultural and/or audio-visual goods. Also, we suggest that, to a certain extent, the same process took place in Latin America.

Methodologically, an empirical study was made, based on the analysis of data of foreign policy during the Chávez era. This data was interpreted in the light of an approach

\footnotetext{
* Pontifical Catholic University of Rio de Janeiro (PUC-RJ), Rio de Janeiro-RJ, Brazil; pablovictorfontes@ gmail.com. ORCID iD 0000-0001-5138-6773.

** University of the State of Rio de Janeiro (UERJ), Rio de Janeiro-RJ, Brazil; monicaleitelessa@gmail.com. ORCID iD 0000-0002-9332-2345.
} 
bringing together critical theory and politics. The article is divided into five sections, firstly outlining the general context, then considering culture and media, Venezuelan cultural policy during the Chávez Era, and new cultural production, before offering the conclusions we have drawn.

\section{The general context}

From the 1970s on, the international system underwent noteworthy structural changes. In turn, these changes were oriented by many crises which had different attributes. However, they were not always interpreted as evidence of a planned change in the international order. Thus, as Fiori (2005: 90) points out, when the Unites States abandoned the Bretton Woods system in 1971, its decision was widely interpreted as a consequence of the US economic crisis and of its inability to secure the international monetary order established in 1944.

However, the dominant interpretation of the '1970s crisis, which highlights the US defeat in Vietnam, the dollar crisis and the oil crisis' (Fiori 2005: 95), does not explain continued US economic growth. Fiori (2005) argues that it also does not explain how the USA advanced its national capital growth through unilateral actions at the international level, nor how it continued pursuing the return of the multipolar order. First, together with England, the USA carried on a globalisation policy for the European capital markets, taking care that 'the interest rates reflected national differences in capital productivity' (Fiori 2005: 95). Then, the USA advanced again when Nixon's government (1969-1974) stepped up against the National Financial System control devices - which has been subject to the Glass-Steagall Act since 1993 - and, at the same time, promoted dollar devaluation aiming at the 'expansion of American capital and the maintenance of American autonomy to manage its domestic policy' (Fiori 2005: 95).

In synthesis, Fiori (2005: 95) observes that the USA structured three complementary strategies so that it could face 'the consequences of its own expansive policies.' During Nixon's administration, 'the return of a multipolar world, accompanied by a liberal and deregulation-oriented international economic policy', sought to increase American power - including the signing of the 1972 Shanghai Statement with China, which 'blocked the possibility of a Russian hegemony in Southeast Asia' (Fiori 2005: 98). During the Carter administration (1977-1981), the Democrat strategy was guided by 'a recovery of America's moral and messianic leadership in the world, combined with a Keynesian international economic policy led by a joint action by the United States, Germany, and Japan, which was intended to become the locomotive of world growth' (Fiori 2005: 98). And during Reagan's government (1981-1989), in order to put an end to the Soviet Union and to build a new global order under the USA's 'irrefutable command, the 'victorious' strategy was to combine 'Carter's Anti-Communist Messianism with Nixon's economic liberalism' (Fiori 2005: 98).

It is important to highlight that the neoliberal program has been in progress since the 1970s, and also that financial deregulation was its central element. In this sense, the 
neoliberal programme created the conditions for an increasingly speculative inversion in detriment to productive speculation. Thus, it was not by chance that the 1980s saw 'a real explosion of the international exchange markets whose entirely monetary transactions eventually diminished world trade in real commodities' (Anderson 2012: 9).

As Ianni (2003: 15) puts it, the recurrent use of metaphors such as 'world-economy', 'world-system,' 'global capitalism,' 'global village,' 'deterritorialization,' 'globalisation,' 'global shopping centre', and so on, to describe the phenomenon of globalisation epitomises the conceptualising difficulty in knowing what globalisation is. Also, we must understand that 'the metaphor becomes more authentic and alive when we recognise that it practically renounces the word by making the image prevail, as a form of communication, information, and fable' (Ianni 2003: 15). Moreover, each metaphor translates its author's perspective on what globalisation is and, sometimes, it is also the concept that defines it.

As Wallerstein conceives it by presenting the concept of the 'world system,' globalisation constitutes a feature of capitalist economies through the internalisation of capital. But, as Held and McGrew (2001) emphasise, it is from the 'golden age' of political and economic interdependence's rapid expansion onwards, i.e., from the 1960s onwards, that the term 'globalisation' came to be effectively used. The authors also distinguish different definitions of globalisation from the emphasis attributed 'to the material, spatiotemporal and cognitive aspects of globalisation' (Held and McGrew 2001: 7). These aspects correspond to the intensity of trade, capital and people flow, to different types of infrastructure ('transportation or banking systems'), to regulations ('commerce rules'), and to the symbolic ('like English used as lingua franca'), respectively (Held and McGrew 2001: 7). Through globalisation, we can see the redefinition of the sovereign nation-state which aims at a global integration in the economic, political, cultural and environmental fields. But for 'sceptics', globalisation is a myth more linked to enthusiasm than to rigor.

In 'perverse' globalisation, Milton Santos (2015: 37) observes the 'emergence of a double tyranny, that of money and information', in which 'competitiveness, suggested by production and by consumption, is a source of the new totalitarianism,' of the 'shrinking of the social and political functions of the state and of poverty expansion, and the increasing aggravation of sovereignty, while expanding the political role of companies in the regulation of social life.' The 'tyranny of information and money' is constitutive of this process and engenders 'fragmented perceptions,' 'the basis of new totalitarianisms that is, the basis of globalitarianisms' (Santos 2015: 37).

During the 1980s, a period well known in Latin America as the 'lost decade,' a scenario of severe economic and social crisis prevailed due to the lack of external credit supply and the lack of efforts to repay the countries' external debt. But, even during these troubled times, the paradigm of dependent development, which leaned on international capital, was not repealed (Santos 2000: 37). Accordingly, as Santos emphasises, this crisis would have contributed to the weariness of military dictatorships. However, it did not determine the overthrow of these governments. Such events would only take place because US interests were redefined as a result of its state-led policy of globalisation since the 1970s.

Opposition to the neoliberal offensive was expressed in several parts of the world, but it only achieved international impact with the Zapatista Movement in Mexico, in January 
1994. As a result, this movement led a wave of protests against the North American Free Trade Agreement (NAFTA) under the slogan 'Ya Basta'1 ('That's enough!', in English). Not long after that, in 2001, the first World Social Forum (FMS) in Porto Alegre brought together protesters from all continents on a front that opposed the globalisation neoliberal policies, in particular NAFTA and Free Trade Area of the Americas (FTAA) agreements. Further, more protests against the World Trade Organization (WTO), the G7, the World Bank and the International Monetary Fund (IMF) took place in Nice, Prague, Quebec and Davos. $^{2}$

In Latin America, the most compelling opposition to neoliberal policies of globalisation, condensed in the Washington Consensus, came through the elections of progressive governments: Hugo Chávez (1999) in Venezuela, Nestor Kirchner (2002) in Argentina, Luís Inácio Lula da Silva (2003) in Brazil, Michele Bachelet (2005) in Chile, Rafael Correa (2006) in Ecuador, Fernando Lugo (2008) in Uruguay, and Daniel Ortega (2006) in Nicaragua.

However, it was Hugo Chávez's Venezuela that highlighted denunciations about local economic elites' 'growing strategic submission' in relation to the USA (Carmo 2007: 26). This was often done through media speeches. In other words, these denunciations took place through Chávez's political rhetoric which was focused in the fight against 'corruption,' 'imperialism,' 'American foreign policy', the Venezuelan people's 'poverty', and 'cultural discrimination' against the indigenous and African populations. It is important to highlight that this rhetoric was largely facilitated by a background of the extreme poverty rate of Venezuelans. A negative legacy attributed to the governments of Rafael Caldera (1969-1974 and 1994-1999) and Carlos Andrés Perez (1974-1979 and 1989-1993). Accordingly, at the regional level, the proposal of 'a $21^{\text {st }}$ century socialism' and the Bolivarian Alliance for the Peoples of Our America (ALBA) demonstrated the ambitions of Chávez's policy. This movement polarised Venezuela, disrupted the conservative forces of other Latin American countries and established the hemispheric power. In addition, as Carmo (2007: 26) points out:

What shocks about Chávez is that the actions proposed by him move in the opposite direction of Latin American trends; it is not simply an anti-liberal stance, it is an anti-technocracy stance. The transfer of powers to technicians accompanied the processes of redemocratization and the implementation of neoliberal policies; the decisions on public policies began to take a form of technical decisions, emptying the political debate about those interests that favoured them. Chávez promotes the opposite movement, restores politics as a foundation of State choices, and thus reveals conflicts of interests behind seemingly technical decisions. The result is that all decisions made by Chávez assume the character of a political decision. This restores the power of the State, but at the same time facilitates the questioning of decisions taken by the government because it does not hide that it aims to benefit certain social sectors and not to make a technical and 
neutral decision. To the extent that the interlocutors want to speak in the name of technique and neutral decisions, dialogue becomes impossible because they tend to question the legitimacy of all decisions taken by the Chávez government because they have a political and non-technical justification.

To begin with, Chávez did not hesitate to intervene in two strategic sectors in order to establish the political stability of his government: the oil sector, dominated by Petróleos de Venezuela S.A. (PDVSA), and the media, dominated by Cisneros Organizations. PDVSA is a Venezuelan state-owned corporation, the third largest oil producer in Latin America, and the fifth largest in the world. In addition, Venezuela holds the largest oil reserves in the world. Especially since the 1970s, this privileged situation meant that Venezuela's main economic activity would be totally focused on oil refining operations, responsible for more than $90 \%$ of national revenues, at the expense of the agricultural and industrial sectors. Another important fact concerns the total production of PDVSA. We can observe that $54 \%$ of its oil is exported to the USA and to Canada, that $19 \%$ represents domestic consumption, and that the rest is sold to various buyers. It should be pointed out that during Chávez's government there was an effort to diversify this clientele, including special conditions for Caribbean countries and for China. Also, the creation of an association (PetroAmérica) formed by the meeting of state-owned companies, was proposed for Brazil, Argentina and Bolivia with the purpose of ensuring the supply of these countries and acting together in the international market (Costa n.d.).

In the case of the audio-visual sector, and like the existing model in Latin America (Lichtenberg 1990: 102; Hallin and Papathanassopoulos 2002: 3), the most important Venezuelan company is a family oligopoly strongly associated with international capital and structured according to the regional political authoritarian image. Cisneros Organization is a media conglomerate which controls $60 \%$ of this market. It includes digital media, real estate investment, supermarket chains and tourism. Also, it emerged in 1961 when Venevisión was founded, and to this day it remains Venezuela's main commercial TV channel. In the 1980s, Cisneros founded Chilevisión, in Chile, and TV Caracol, in Colombia. Besides, it also has a significant shareholding in Latin American DirectTV, whose satellite broadcasts sports programs, game shows, soap operas and light news for twenty Latin American countries. The group also has a shareholding in Univisión, the main Spanish-language channel in the United States and has a Latin American joint venture with AOL-TimeWarner (Gott 2014).

For its part, the public sector is composed by Venezolana Televisión (VTV), created in 1964 and nationalised in 1976, and by TeleSur, created in 2005. Other open channel options are offered or can be accessed via the Internet, such as Globovisón en Directo, NTN24 Noticias, RT Noticias, Unión Radio online, Noticias Univisión, La Patilla Sucesos and $\mathrm{BBC}$ online.

Therefore, it was in this environment hostile to the ideals of ' $21^{\text {st }}$ century socialism' that Chávez established his policy priorities: to overcome Venezuela's economic submission to the USA; to promote the re-foundation of national cultural policy, in order to 
reconstitute the Venezuelan social fabric through an inclusive cultural policy ${ }^{3}$ prone to development; to establish ' $21^{\text {st }}$ century socialism'; and to advance the integration project of ALBA.

Once elected, Chávez tried to make the possible changes in the energy sector and in the area of culture, including the audio-visual sector. But his break with the neoliberal agenda, as Carmo (2007) analyses, partially frustrated these projects. Also, after his inauguration, Chávez was obliged to abide by the agreement with the IMF, which compromised part of his reforms promise, mainly those related to the agrarian and oil sectors. Therefore, in order to face external pressures, the international performance of the country became a strategy to be reached through public and media diplomacy ${ }^{4}$ (Yip, Filho and Souza 2014: 26).

[...] Neighbouring countries' adhesion to the projects proposed by Hugo Chávez increases the legitimacy of the Venezuelan project in the international system and, this way, reduces the spectrum of viable US actions against Chávez's government. [...] But, at the same time, the integration projects presented by Caracas are always political; they are justified not only by technical reasons (even if there are technical reasons), but for reasons of power. Integration becomes a means of increasing the power of the South American states in the international system, or at least reducing the degree of dependency; therefore, Chavista integration is always against something, against US economic and political domination in the region, because it aims to complement Chávez's internally developed project of reducing dependency. For this reason, despite pleading for an entry into Mercosur, Chávez simultaneously proposes new integration projects and attacks Mercosur (Carmo 2007: 28).

\section{Culture and media}

Chávez considered recreating Venezuelan cultural and media policy an essential option to gain support from popular sectors and to achieve political stability. For this purpose, cultural and media policy should be able to ensure inclusive social development and the representation of popular cultural identities. In this sense, it is important to bear in mind that culture is a 'system of collective reference to each State/society' and is considered 'one of the foundations of states' foreign policy, which it contributes to influencing' (Milza 1980: 362). Hence, it acquires a decisive role in the countries' policies. ${ }^{5}$ That is, 'culture, understood in its broadest sense - namely the production, diffusion, and consumption of symbolic objects created by a society - constitutes, first of all, an agent or factor of international relations, in so far as that it shapes mindsets and guides public sentiment' (Milza 1980: 362).

According to the critical aspect of the Political Economy of Communications, and in terms of communication, the media is part of the capital accumulation process and of the 
ideological reproduction of the capitalist system. From this perspective, we consider that 'communication that takes place in the productive process of the capitalist kind consists of a hierarchical, bureaucratic communication that is compatible with a factory power structure' (Bolaño 2000: 41). Therefore, there is no unbiased, neutral information. There is, however, 'the possibility of using information as a means of political domination, as propaganda.' (Bolaño 2000: 41). Or as 'non-truth', that is, information being manipulated in several ways. Another important point to consider is that 'the masses are nothing but an abstraction that masks the concrete reality of class contradiction' and that 'the capital and the state create a mass with which they communicate. They create it to communicate with it, but, in general, they do not do it directly, but through a mediating element: the Cultural Industry' (Bolaño 2000: 94).

Figure 1: The Cultural Industry

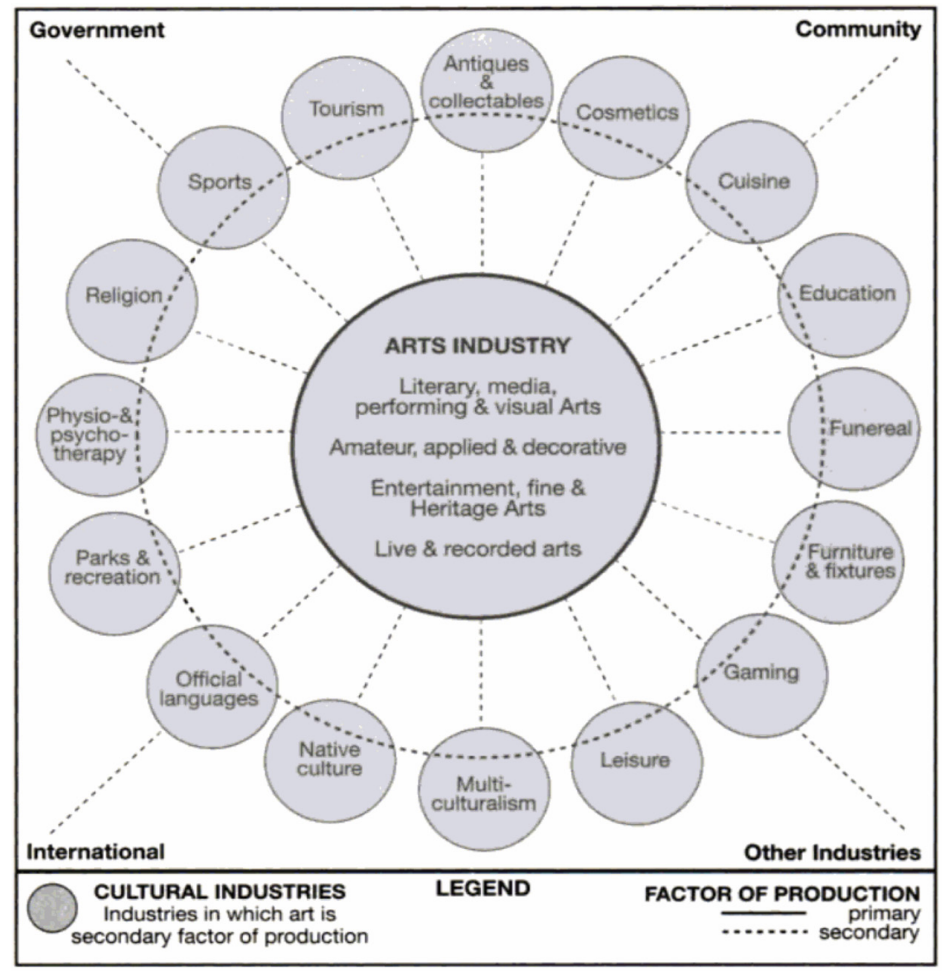

Source: Chartrand (2000: 25).

Milton Santos presents the concept of 'information violence' ([2000] 2015: 38). According to the author, in the globalised capitalist system, this information violence corresponds to the manipulation of information and can be observed in the partiality of narratives, marked by the absence of inconsistencies, by the lack of clarity concerning all the data involved, by an ideological rhetoric minimally masked by superficial impartiality, and easily associated with globalising discourses. Therefore, Latin American communi- 
cations companies, mostly family oligopolies, dependent on international news agencies, find themselves globalised by the reproduction of their guidelines and aesthetics.

Since the 70s, communication, and policy studies considered the transfer of cultural technologies equivalent to a transference of global models of power organization. The technology's importance concerning new communication in mass cultural production, allowed the interconnection between the private and the public. It was a phenomenon described by Mattelart and Schmucler (1983) and an important tradition of Latin American studies. [...] however, the results of these researches-developed since then-converge to one aspect: media's centrality, that of the television in particular, in constructing political scenarios that characterise the new Latin American democracies of the 80 s. The possibility of a democratic contribution, as well as democratizing politics of the media in general has been evaluated in the inverse ratio of the degree of oligopolistic concentration of the means and in the direct reason of the party's importance in each context (Sarti 2000: 1).

With regard to previous decades, the new phenomenon (of television hegemony) is that, in the $21^{\text {st }}$ century, the technological advances of communication - Internet, personal computer, cellular phone and IPTV - revolutionised the information pattern of production and consumption. Also, it happened to the cultural industry's content and consumption. On the one hand, we saw the emergence of social networks ${ }^{6}$; on the other, we saw the emergence of alternative media. This way, counter-hegemonic media and their practices of contradiction confronted larger conglomerates of information, generating unequivocal and continuous debates with journalism 'at the service of the establishment' (Bolaño 2000: 71). Also, as the author puts it: It is only with monopoly capitalism and especially with the emergence of the so-called Cultural Industry that information acquires the unusual relevance it has acquired in maintaining the system, both from the point of view of its ideological reproduction and that of its own accumulation of capital (Bolaño 2000: 71).

John Postil (2012) points out that political actors (politicians, activists and religious leaders) are increasingly using digital media and social networks. He also observes a considerable increase in the adherence of new marketing techniques that indicate a tendency towards a 'digital state' construction and towards a more positive search for images, not only of the political man but also of agencies belonging to the state:

Digital government is connectivity. The digital democracy field has at its core the concept of the 'public sphere, associated with the social philosopher Jürgen Habermas. A public sphere is 'an arena, independent of the government [and of the market] [...] dedicated to a rational debate and which is both accessible to and open to inspection by citizens' (Postil 2012: 166). 
In Latin America, alternative digital media have played a significant role in disputing space with the digital media of large communication groups. For their part, these groups were historically characterised by the (re)production of the region's authoritarian political tradition. It is the existence of media oligopolies that ensures the (re)production of an authoritarian political tradition during and after the construction of narratives and discourses conveyed. This happens because they are marked by an 'electronic coronelism' (Santos 2008: 224) in their practices, ${ }^{7}$ and by the matrix structure and organisation of capitalism that unify and standardise everything. Also, these oligopolies include discursive selectivities in the versions and imagery of their frames (Santos 2008: 224).

Even bringing together the four largest media and entertainment companies in the world, i.e., Globo Organizations (Brazil), Televisa (Mexico), Clarín Group (Argentina) and Cisneros Group (Venezuela), Latin America continued to record low revenues in the sector in focus until 2009 (Moraes 2009: 112). In 2000, the USA alone accounted for 55\% of the world's incomes, followed by the European Union, at about 25\%, and by Japan and Asia at about 15\%. Among the reasons presented in this situation, G. Moraes (2015: 112) considered lower revenues, the little relevance in the international market, and the negligible investments made in technology and in the production of media content.

In turn, between 1994 and 2003, according to UNESCO data, cultural goods and services accounted for more than 7\% of world's GDP, making the cultural economy the fastest growing sector in world's economy. This significant increase in global cultural flow corresponded to the advance of globalisation policy. This advance was the subject of a Franco-American dispute, during the passage from the GATT to the WTO, on cultural goods and services liberalisation, which was synthesised in the clause of 'cultural exception' adopted at the end of the Uruguay Round (1986-1994), ${ }^{8}$ and was the pivot for the adoption of the Universal Declaration on Cultural Diversity (2005) by UNESCO.

It was in this international environment with strong emphasis on culture that Hugo Chávez conceived the unprecedented cultural and media policy promoting the Venezuelan audio-visual sector. However, due to a number of factors and characteristics of Venezuelan politics and to characteristics of Latin America's own cultural industries, exports of cultural goods and services throughout the region remained on the sidelines of a vibrant international trade in cultural goods and services (Lessa 2012), as shown by the data published by UNESCO in the report The globalisation of cultural trade: A shift in consumption - international flows of cultural goods and services 2013-2014 (UNESCO 2015), and in Table 1 and Figures 2 and 3.

Table 1: Annual worldwide growth rate for cultural goods between 2004 and 2013.

\begin{tabular}{lccccccc}
\hline $\begin{array}{l}\text { Growth } \\
\mathbf{2 0 0 4 - 2 0 1 3}\end{array}$ & $\begin{array}{c}\text { Total } \\
\text { cultural }\end{array}$ & $\begin{array}{c}\text { A. Cultural } \\
\text { and natural } \\
\text { heritage }\end{array}$ & $\begin{array}{c}\text { B. Performance } \\
\text { and } \\
\text { celebration }\end{array}$ & $\begin{array}{c}\text { C. Visual arts } \\
\text { and crafts }\end{array}$ & $\begin{array}{c}\text { D. Books } \\
\text { and press }\end{array}$ & $\begin{array}{c}\text { E. Audiovisual } \\
\text { and interactive } \\
\text { media }\end{array}$ & $\begin{array}{c}\text { F. Design } \\
\text { and creative } \\
\text { services }\end{array}$ \\
\hline Exports & $96,2 \%$ & $45,4 \%$ & $-17,8 \%$ & $185,6 \%$ & $16,3 \%$ & $111,9 \%$ & $-28,2 \%$ \\
\hline Imports & $52,0 \%$ & $57,3 \%$ & $-17,8 \%$ & $101,0 \%$ & $12,4 \%$ & $111,9 \%$ & $-11,3 \%$ \\
\hline
\end{tabular}

Source: UNESCO, cited in Institute for Statistics (UIS) 2015 (based on data from UN Comtrade, DESA/UNSD). 
Figure 2: Export distribution of cultural goods in each region of the world

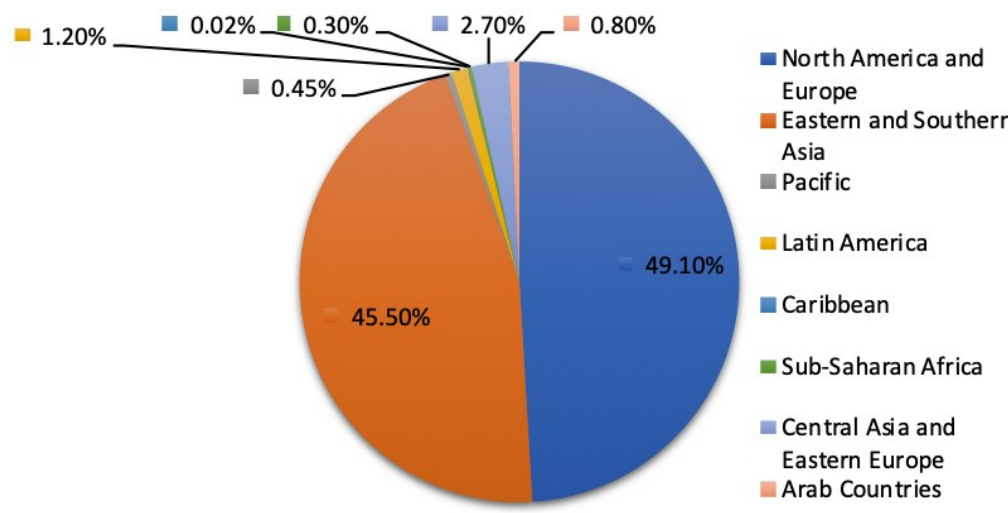

Source: Created by the authors based on UNESCO (2014)

Figure 3: Regional distribution of cultural goods and all goods exports in 2013

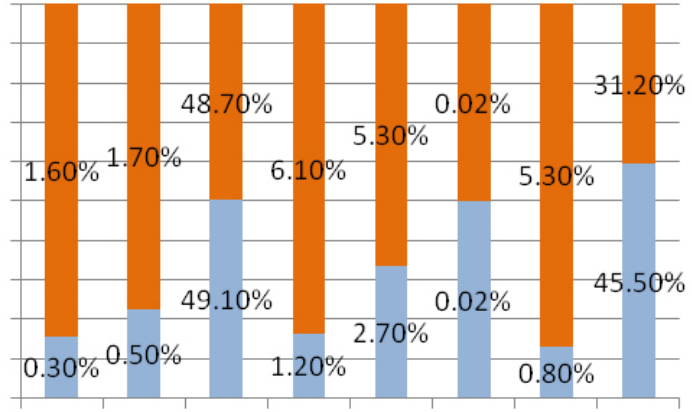

all Goods

Culture Goods

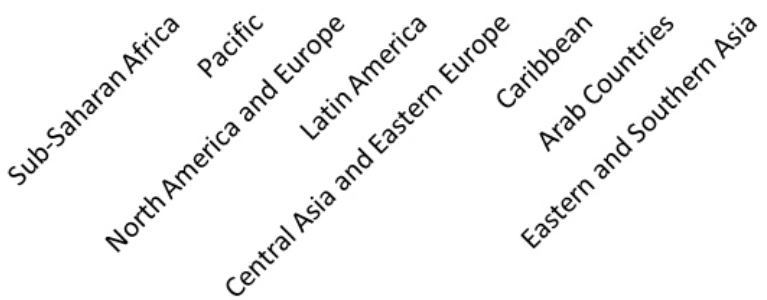

Source: Elaborated by the authors based on UNESCO sources (2014).

\section{Venezuelan cultural policy in the Chávez Era}

With regard to Venezuelan foreign policy, we observe that between 2003 and 2009 a change in the national cultural policy was promoted. According to some interpretations, this change occurred in a period in which antagonistic peripheral revisionism was in force. 9 In April 2002, Chávez overcame a coup attempt led by the President of the Venezuelan Federation of Chambers of Commerce (Fedecámaras), Pedro Carmona. It is important to 
highlight that this coup was articulated with former PDVSA executives, opposition military and conservative elites, and also witnessed the broad involvement of private media. However, in the search for governability while facing these challenges, Chávez requested a referendum that brought him back to the presidency with popular approval: $58.25 \%$ of the valid votes (Serpa 2014: 137).

The coup of 2002 made Chávez decide almost immediately to assign the state with means of communication able to match the private media opposition. It should be borne in mind that the private media had the support of the state television technocracy and that Chávez was seeking to secure the right to establish fundamental communication with the masses. As Bolaño (2000: 94) analysed, and we repeat, that entity is nothing other than an abstraction that masks the concrete reality of class contradiction' and that 'capital and the state create $[. .$.$] to communicate. They create it to communicate with it, but, in general,$ they do not do it directly, but through a mediating element: the culture industry.'

Until 2002, private television networks prevailed in Venezuela. On average, $60 \%$ of the audience belonged to the television networks that held about $80 \%$ of the information on channels with 24-hour content transmission per day. In addition, printed newspapers held by private companies made it difficult to criticise any information used to oppose Chávez. In this sense, programmes such as Aló Presidente (Hello President, in English) (1999) and the creation of TeleSUR ${ }^{10}$ (2005) were designed as a means to promote Venezuela's reputation both in the domestic and the international scenarios and deconstruct the negative image of Chávez's government.

According to Kfuri and Flores (2009: 2), through the documents 'The New Strategic Map' (Harnecker 2004:11) of 2004, and 'General Lines of the National Economic and Social Development Plan 2007-2013', together with his team of policymakers Chávez elaborated a new geostrategic and geopolitical design for Venezuela.

Venezuela has advanced in an accurate and sustained manner in the fulfilment of the international balance goals foreseen in the General Lines of the Economic and Social Development Plan 2001-2007. National sovereignty was strengthened, and progress was made in the construction of a multipolar world, and in Latin American and Caribbean integration and international relations diversification, that constitute the mainstays of our foreign policy; this has resulted in Venezuela having had an important positioning growth in the international scenario. In the last seven years, the Bolivarian Revolution has implemented an intense foreign policy, breaking with the historical passivity that characterised Venezuela's relationship with the world, in which the fundamental element was the mediatization and subordination to the geopolitical interests of US imperialism. Currently, Venezuela regained its independence and sovereignty in its international agenda formulation. The new circumstances at force determine that Venezuela is moving towards a new stage in world 
geopolitics, based on a strategic relationship of greater clarity in the pursuit of objectives of greater world leadership (Chávez 2007: 44).

According to official documents of Venezuela's government, as Latin America and the Caribbean came to prominence, the construction of a 'New Mercosur' rested with Venezuela (2006). The creation of the Union of South American Nations (UNASUR), whose constitutive treaty was signed on 23 May 2008 in Brasilia, was also an interest of the Bolivarian Republic. In addition, official documents at the time stated that it was also necessary to strengthen, to intensify and/or even to extend socio-political and economic relations with Central America and Caribbean countries. In this sense, ALBA sought to boost and to consolidate ideas that would bring an alternative bias to the FTAA (Valente 2012: 97).

Data collected from the latest UNESCO world report entitled 'Investing in cultural diversity and intercultural dialogue' (UNESCO 2009) reiterate that, since 2006, 'media and cultural industries' have averaged more than $7 \%$ of the world's GDP, whose approximate value is US\$1.3 trillion. During the 1990s, the cultural sector grew on average by twice as many service sectors and four times as much as other industry branches. But it has not been observed that the changes pursued since the MacBride ${ }^{11}$ Report have been achieved because there has not been a decrease in economic inequality among countries, nor has the level of concentration of multinational companies in developed countries remained constant. We observe this concentration in the broadcasting and film production sector, in which most developing countries do not present competitive conditions.

In Latin America, there has been an expansion of pan-regional and international information networks. In this sense, possibilities for alternative voices have emerged. However, the subcontinent remains inexpressive in international trade even though the world media scenario presents some changes, starting with the export of cultural equipment and communication products, called 'counterflows.' The following charts (Figures 4 and 5 ) indicate the government's efforts to promote Venezuelan production and export of cultural goods, in large directed to the Latin American region, but not only to this. Most of these exports comprise several products ranging from regional literature to television, and audio-visual productions.

Figure 4: Total exports of cultural goods

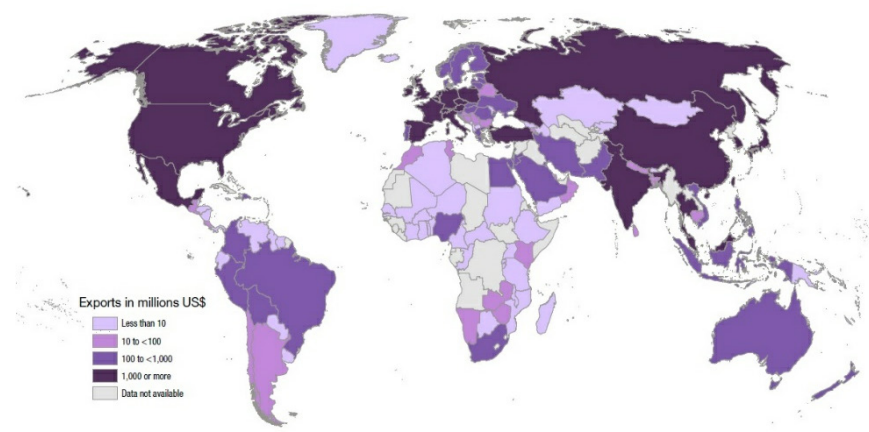

Source: UNESCO (2014). 
Figure 5: Total imports of cultural goods

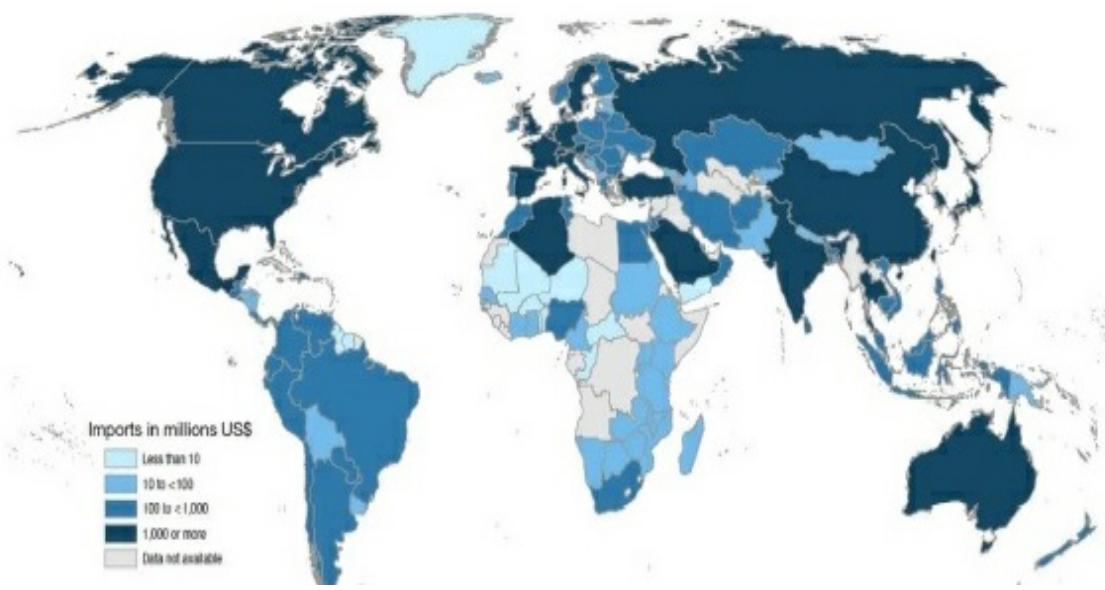

Source: UNESCO (2014).

Regarding Venezuela, Figures 6 and 7 show the index of exports and imports of cultural goods from 2004 to 2013.

Figure 6: Exports of Venezuelan cultural goods (2004-2013)

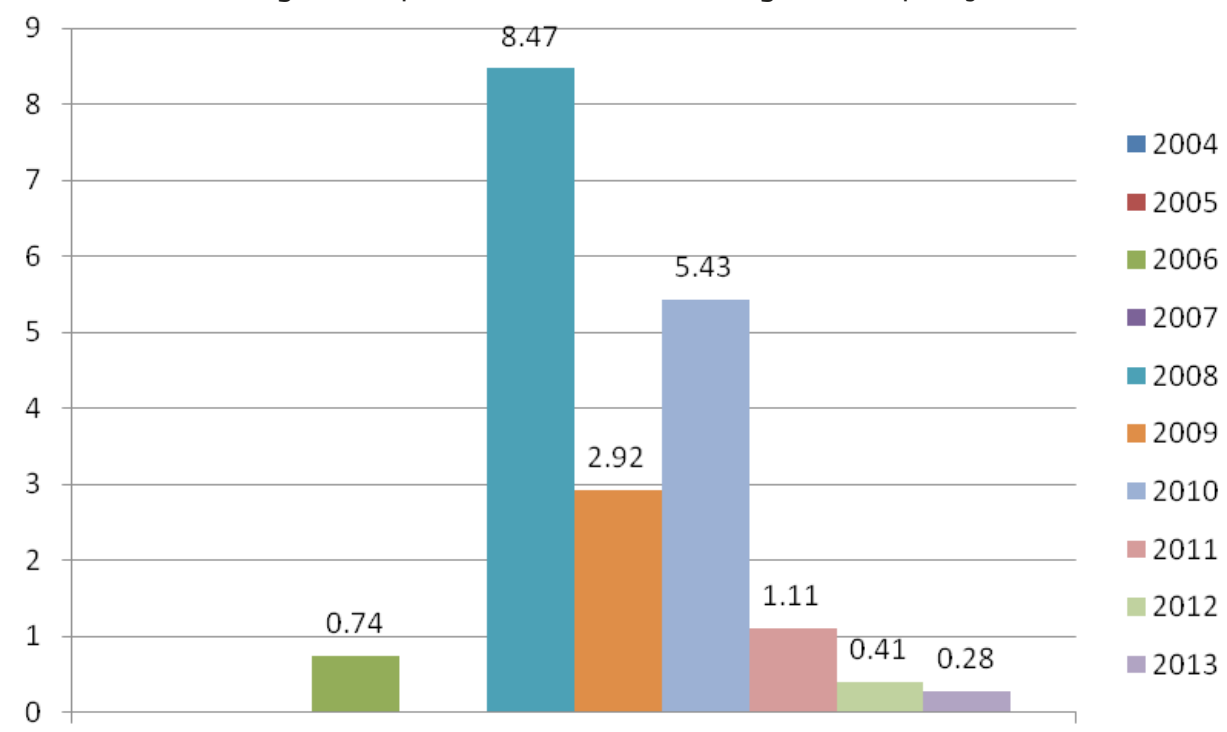

Venezuela

Source: Elaborated by the authors. Based on UNESCO (2014) 
Figure 7: Import of cultural goods from Venezuela (2004-2013)

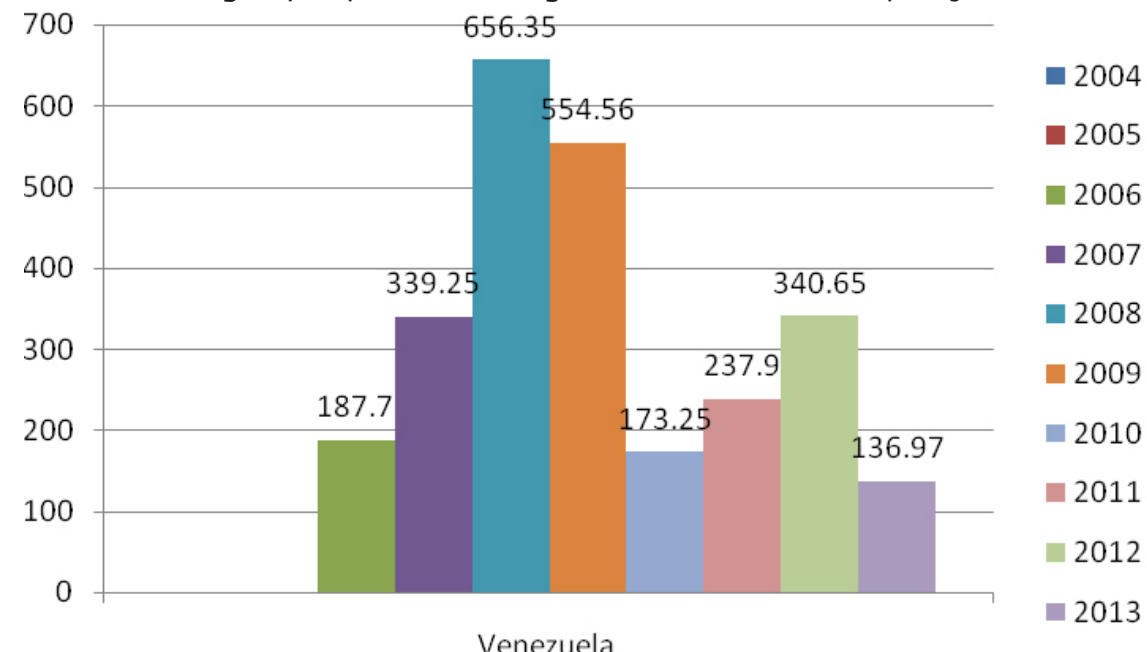

Source: Created by the authors based on UNESCO (2014).

During the Chávez Era, political polarisation led to a strong rejection of any kind of private monopoly on media. At the opening of the Fifth World Meeting of Intellectuals and Artists in Defence of Humanity, organised in Bolivia in 2007, Chávez made severe criticisms of the media and its work in the Southern Cone (Moraes 2011: 65). On this occasion, he did not preach the need for a total restructuring of the entire technological park of Venezuelan culture and media, although, during his term of office, Chávez created and invested in the creation of organs in the cultural area, including the inauguration of four new TV channels: Vive TV, Venezolana de Televisión (VTV), Ávila TV and Asemblea Nacional (Moraes 2009: 120).

During this period there was also the creation of the radio stations National Radio and World Radio (AM system), as well as the news agencies Agencia Venezolana de Noticias and Imprenta Nacional and other new cultural organisations, such as Fundación Vicente Emilio Solo (a music institute) and the Centro Nacional de Tecnologías de Información (Moraes 2009: 120).

Some other changes in the communications sector came as a result of the referendum votes on the proposed constitutional reform in December 2007. Accordingly, for the first time Chávez lost an election by $49.35 \%$ of the votes against $50.65 \%$. In 2010, a new referendum gave Chávez the expected victory - this time the referendum was about a constitutional amendment aiming at indefinite re-election for all positions on popular election, including that of President of the Republic. The defeat of 2007 imposed a new political calculation on Chávez, who recomposed his ministries, including on the agenda the so-called three 'Rs' of the Bolivarian Revolution. According to Moraes (2009: 121), the establishment of the three 'R's' aimed at the revision, the rectification and the relaunch of 
the revolutionary process in a logistics that sought to confront the media's artillery against the government and the economic problems that devastated Venezuela - mainly the crisis of commodity prices, such as oil, that were already affecting the world market (Jesús Silva 2008). Chávez sought to redesign the National Public Media System through the Ministry of Communication and Information to achieve two main objectives: to restructure government vehicles and to seek greater circulation through alternative and community media. Therefore, his government evidenced the imminent break with the national oligarchy.

In search of a unique and specific format, television schedules were changed. The changes also sought co-operation through the exchange of information and content between national and Latin American broadcasters. VTV became a news channel, while National Radio of Venezuela (RNV) turned to cultural, informational and youth segments. Ávila TV began to direct itself towards children and adolescent audiences. Vive TV prioritised community participation. As far as content production is concerned, the Instituto de Radio y Televisión (IRT) was responsible for co-ordinating studios, training, and financing the technical structure. In addition, Red TV was created to gather and to distribute signals from government broadcasters.

At the end of October 2008, another innovation was produced in the field of communication and culture. In January 2009, in partnership with China, Venezuela launched the satellite VENESAT I, also called Simón Bolivar, which started to broadcast signals from public and community broadcasters in Venezuela (TeleSUR 2016). The satellite sought to overcome the obstacles and limitations imposed upon Venezuela for years by the private network DirecTV. It is important to mention that the creation of the Agencia Bolivariana de Actividades Espaciales (ABAE) established the control and maintenance rigor of the Venezuelan satellite, and, as some observers noticed, the Simón Bolivar satellite allowed technological independence and enhancement of Venezuelan sovereignty (Moraes 2009: 122).

Another important step taken was the signing of technical co-operation agreements through the mediation of the Bank for Economic and Social Development (BANDES) which enabled Ecuador, then governed by President Rafael Correa (2007), to obtain financing for the inauguration of the Ecuadorian channel TV in December 2007. Other movements for informative co-operation were carried out with Southern Cone countries. Official agencies of Venezuela (AVN) exchanged news and information with Argentina, Brazil, Uruguay and Ecuador. According to Moraes (2009: 120), informative circularity agreements allowed the distribution and the dissemination of a new conventional media estuary.

Bolivia was another country favoured by technological co-operation agreements. Through Venezuela's BANDES, Bolivia managed to capitalise around US $\$ 5 \mathrm{~m}$ dollars, providing the creation of the Network of Radios of Native People of Bolivia under the motto 'the voice of the voiceless.' By 2017, the network had about 30 stations (20 AM and 10 FM) (Moraes 2009: 158). But changes in media and culture did not stop. Hugo Chávez produced and released print newspapers with online versions as a mechanism to publicise actions in the media, avoiding the blockade of mainstream media. According to Moraes 
(2011: 65), the target public was the lower social classes that the government sought to captivate by selling at much lower prices. On the other hand, the printed newspapers sought to discuss the facts and events from the government's perspective. Another goal of these newspapers was to counter the accusations and criticisms made by liberal media.

On 30 August 2009, Chávez launched Correo Del Orinoco. The debut of Correo Del Orinoco was a print run of 50000 copies with approximately 32 pages. This Venezuelan newspaper was strongly influenced by the journalistic style and editorial line of the famous newspaper Gazeta de Caracas, which circulated between 1818 and 1832, during the Venezuelan war of independence. Gazeta de Caracas aimed at struggling for independence and criticising the Spanish crown. Correo Del Orinoco resisted and surpassed the interferences of the Chávez government, although most of the news reflected information coming from the Miraflores Palace (Moraes 2011: 67).

\section{Between TVs and community radios: towards a new cultural production}

Innovations also marked Venezuela in 2005, mainly since the creation of the Venezuelan Law of National Cinematography. According to this law, national cinema would be protected from American and European influence and hegemony (Asemblea Nacional [Bolivarian Republic of Venezuela] 2005). That would happen because of the determination of minimum permanence of the national cinematographic releases: three weeks in the movie theatres. This determination forced movie production companies to market at least 20\% Venezuelan films. The National Autonomous Centre of Cinematography (CNAC, in Spanish) began to apply minimum quotas to protect Venezuelan productions. On average, five national audio-visual content viewing rooms were to be available for film screenings for up to 12 weeks.

As Moraes (2009: 173) puts it, investments in culture during the Chávez Era were expanded to finance 500 popular communication projects, including audio-visual media, 205 print newspapers, 100 digital newspapers, blogs and Internet portals. In community terms, the National Movement of Alternative and Community Means (MoMAC, in Spanish), created in 2008, allowed the creation of minimum quotas in order to protect Venezuelan productions. The law also allowed distributors to profit from ticket prices. These profits varied between 30 and $60 \%$, depending on how long the film remained on show (Moraes 2009: 175, 2011: 66).

The Venezuelan Ministry of Communication held meetings with a reasonable periodicity in order to discuss technical standards and journalistic quality improvements. In addition, the meetings allowed the offer of funding and subsidies to the community media. The Community Cultural Network sought to broadcast programming, film samples, exhibitions and theatre performances in the outskirts of Venezuela (Moraes 2009: 162).

It is worth highlighting that all of these programmes and laws could only be created from PDVSA oil profits. Thus, oil and its derivatives were essential for cultural and media policies (Fontes and Renni 2016: 66). 


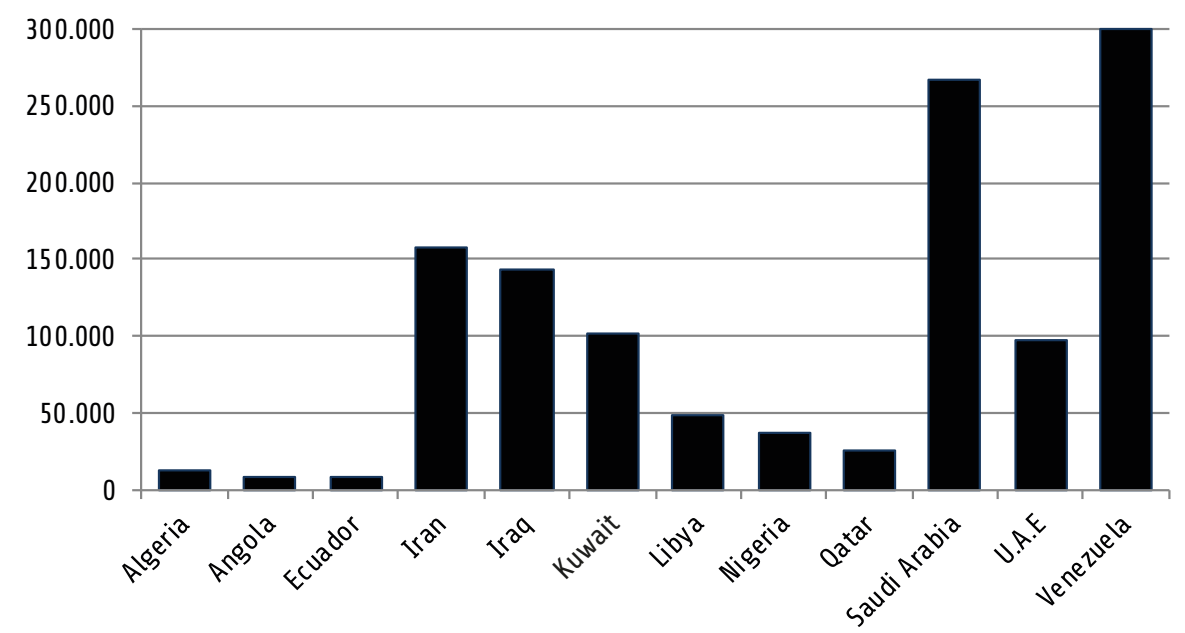

Source: Fontes and Renni (2016: 66).

The creation of Cultural Funds also happened through PDVSA financing. According to the strategic plan of the Cultural Funds, the distribution of audio-visual content networks could be shared and displayed in regional integration projects such as ALBA. PDVSA also sponsored the International Film School in La Guaira, whose mission was to train movie production staff. In 2006, Chávez inaugurated Villa Del Cine, near Caracas, whose purpose was to create a cultural complex.

All these measures aimed at facing the Hollywood industry. According to Moraes (2009), because of this purpose US $\$ 42 \mathrm{~m}$ was invested in pre-production and post-production facilities and studios. The National Cinematheque began to strengthen cinematic activities, including the expansion of audiences at the regional level through the audio-visual poles. However, despite all these important cultural and media innovations, vis-à-vis the US and European media hegemony, an important part of the Venezuelan population, specifically Indians, blacks and mestizos, was not represented in the television and film content produced.

A large part of this population understood that the Chavista media-cultural innovation aimed at fighting the political-identity exclusion that insisted on keeping 'the mestizos' - the 'other' - invisible (Pieretti 2014: 55). This novelty of Venezuelan cultural policy, also accompanied by considerable economic growth of the cultural sector, was what allowed Chávez to achieve the expected 'communication' with the masses through the means of communication.

Monsoyi proposes a dialectical position of character identity. 'Identity is a dialectical set of specificities both - objective and subjective - acting within a society' (1981: 157). That is the identity that Chavismo adopts, a Venezuelan political identity that is based on 
the dialectic that Chávez generated from the moment of his oath as President on, when determining a difference between past and future to give rise to his project. Maduro's government maintains that dialectic when it promotes power differences among Venezuelans (Pieretti 2014: 60-61).

\section{Conclusion}

The Chávez Era and its proposal for a ' $21^{\text {st }}$ century socialism' prompted Venezuela and Latin America to exhibit a new geopolitical, geostrategic and geocultural performance. From the enlarged Mercosur, ALBA, UNASUR and Banco do Sul, a break with the traditional regional model of development, once dependent on international capital, became real. Carmo (2007) writes that it is notorious that the Bolivarian development project points to an alternative path that breaks with the 'underdevelopment development' logic because it involves society's democratisation and social inclusion.

The significant changes that reconfigured Venezuelan cultural politics represented this attempt to break with the model of dependence and underdevelopment of the production and consumption of cultural goods and services. It is no coincidence that the emphasis of this new cultural policy rested on a media that had as its main characteristics patrimonialism, patronage, electronic 'coronelismo' typical of the Southern Cone region and also a strong association with international interests.

The resources provided by PDVSA were essential for political and cultural transformations in Venezuela, especially after the 2002 coup d'état. It was against this background that Hugo Chávez launched the guidelines for the programmes 'The New Strategic Map' in 2004 and the 'General Lines of the National Economic and Social Development Plan 2007-2013, which, among many changes, pointed to a new architecture of cultural and media assets.

All these transformations carried out by Chávez indicate his efforts to reconstitute the Venezuelan social fabric and to recreate an inclusive cultural identity. In Chávez's view, the diffusion of a positive Venezuelan image corresponded to social justice, to inclusive development, and to expanded cultural identity, referring to all the 'forgotten' people of history: Blacks, Indians and Mestizos. As we saw, though, the cultural policy provided fundamental social changes from the Venezuelan state's point of view, without, however, ensuring political stability and the inclusion of all ethnic groups in Venezuela.

Other initiatives, such as the creation of Correo Del Orinoco and the Network of Radios of the Original Peoples of Bolivia, which allowed about 30 networks of broadcasters (20 AM and $10 \mathrm{FM}$ ) to be developed, represent huge innovations in Chávez's cultural and media policy, just as was the creation of Aló Presidente and TeleSUR, which further reinforced the promotion of the Venezuelan image on the international stage and, at the same time, promoted the regional integration ideal.

As noted in this paper, even after several innovations in the cultural area, the Chávez Era remained characterised by political/identity processes that are sometimes inclusive, 
but also exclusionary when we think about the black, the indigenous and the mestizo populations. Also, for Pieretti, despite his speeches and politics, Chávez also kept these populations in cultural and political invisibility, as their historical and political perspectives were neither addressed nor represented through their economic and cultural demands and aspirations.

Social groups with enough power to support or to endorse what the media in the service of Chávez (public mesosphere) show in order not to leave out the international communication force. It [Chavismo] created its own information channel, its news agency of influence pancontinental: Telesur (macropublic). Thus, with a communication device that embraced all social spheres, Chavismo was able to create, to develop and to sustain a whole policy of identity culturalization and generation around the figure of Chávez (Pieretti 2014: 63).

As noted, the media technological revolution, which started with television claiming to be a vehicle for mass global communication, turned the world into a 'global village.' This way, the ever-widening public and the growing massification of information in an increasingly mediatised society contribute to interests in matters previously circumscribed to the circles of experts in the political, economic and government world. It is 'the media culture and the triumph of the spectacle' that transform sporting and other events or striking political phenomena into 'mega political spectacles' (Kellner apud Lessa 2011:35). Hence the justification of understanding the political importance exercised by the communication and cultural conglomerates in international relations.

More than that, with unprecedented cultural and media policies, Chávez sought the political stability of his government and, at the same time, the regional support of leading the other progressive governments of the region to a new regional insertion in the international system through various policy measures. The use of counter-hegemonic discourses, committed to the deconstruction of contradictory visions produced by the countries of the central economies, relied on national media independent of the great foreign conglomerates, directed to an audience previously ignored by the mainstream media.

\section{Notes}

1 In France, in 1999, Peasant Confederation leader José Bové invested against a fast food chain store to symbolise the anti-globalisation struggle. In November of the same year, at the time of the so-called 'Millennium Round' organised by the WTO in Seattle, thousands of people started demonstrations that lasted several days against 'neoliberal corporate gobalisation' and its threat to the social, economic and ecological balance of the planet, managing to suspend the meeting.

2 According to the IMF, the Group of Seven (G7), Germany, Canada, the United States, France, Italy, Japan and the United Kingdom, accounts for $64 \%$ of global net wealth.

3 Cultural policy is divided into internal and external. In the first case, it is the responsibility of the Ministry of Culture, as the formulator and executor of programmes, actions, projects and activities for artistic expression and national historical and cultural heritage development. It is also designed to ensure cultural 
diversity through co-operation and cultural exchange with other countries. Most countries articulate the symbolic, citizen and economic dimensions, understanding that cultural policy should promote social and inclusive development in a socially just and sustainable way.

4 In the age of information Gilboa $(2001,2002)$ observes three types of new diplomatic practices: public diplomacy, comprising state and non-state actors actions and the use of media and other channels of communication to influence international public opinion; media diplomacy, which is the use of media by governments to communicate with actors and to promote conflict resolution; and media broker diplomacy, when journalists temporarily assume the role of diplomats and serve as mediators in international negotiations. Valente (2007: 90) translated these three modalities as Public Diplomacy, Indirect Media Diplomacy and Media Diplomacy, respectively. Ypi, Andrade Filho and Candido Souza (2014: 26) point out that the Brazilian Foreign Ministry does not adhere to the concept formulated by Gilboa. On the contrary, it adheres to the expression made by the American diplomat Edmund A. Gullion, which he termed public diplomacy to promote America's image abroad (Ype, Andrade Filho and Souza 2014).

5 Several studies on the polysemy of the word 'culture' indicate its importance and complexity. They also show that this word emerged to define an agricultural crop and evolved to define 'a general state or habit of the mind,' 'a general intellectual development situation in a society as the whole body of the arts', or 'a whole way of life, material, intellectual and spiritual' as Raymond Williams observed in Culture and Society (1952: 18). The author highlights how this evolution was contemporaneous with the introduction, or resignification, of the 'Common English' of the eighteenth century, of four other words 'of capital importance': industry, democracy, class and art. That is, culture is 'constitutive of other social processes' and neither a reflection nor a representation of them (Williams 1952: 18).

6 The network is a set of social relations among actors, with little institutionalisation, bringing together groups in a kind of association whose limits are variable and subject to various types of interpretations. One of the first important changes detected by computer mediated communication in social relations is the notion of geographic locality transformation of social relations - although the Internet was not the first responsible for this transformation, which was initiated with the emergence of means of transportation and communication. The beginning of the global village is also the beginning of the deterritorialisation of social ties (Recuero 2009: 135).

7 Electronic coronelism is the result of the overlapping of representative regime forms developed with an inadequate economic and social structure. It is not merely the survival of the private power, but a peculiar form of private power, that is, an adaptation by virtue of which the remnants of our old and exorbitant private power has managed to coexist with an extensive representative base of a political regime (Santos 2008: 224).

8 Broadly publicised by the major international press, the Franco-American dispute attracted the public's attention both to the cultural importance and to one of the possible side effects of globalisation: cultural homogenisation. Finally, progressive liberalisation of cultural goods was adopted (a slower and more gradual process than the indiscriminate liberalisation advocated by the USA), a formula that guarantees the autonomy of countries to develop cultural diversity through subsidies, fiscal incentives, anti-dumping laws, etc. (Lessa 2012).

9 According to Guimarães (2008), between 1999 and 2002 a more discrete orientation, independent of the USA began to be structured in Venezuela's foreign policy. This political phase of Venezuela is understood from a symmetrical and inverse proposal to the pragmatic acquiescence of the 1990s. In this sense, a peripheral revisionism begins to characterise Venezuela's foreign policy, with the purpose of revisiting it based on the asymmetrical relations established between the Periphery Countries with the status quo and with the dominant power. According to the authors, peripheral revisionism must be understood according to system guidelines orchestrated by unitary actors that have a tendency to multipolarity instead of a fragile and unstable unipolarity (Guimarães 2008; Valente 2012).

10 Based on the slogan 'The South is our North' the TeleSUR television network was formally created on 24 July 2005, the anniversary of the revolutionary Simón Bolivar. The network was guided by a multistate property (an alliance among Venezuela, Argentina, Uruguay and Cuba). This way, initially TeleSUR received an investment of US $\$ 10 \mathrm{~m}$ - only Caracas invested about $51 \%$ in information and communication technology, while the other members invested in other technologies and media devices such as Argentina (20\%), Cuba (19\%) and Uruguay (10\%) (Maringoni 2007: 155-156; Fontes 2017). 
11 It is a UNESCO report, released in 1980, which addresses the main problems associated with the media through the collection and dissemination of information from a historical, sociological and political perspective. More than 16 members from all over the world participated in sharing the most diverse thoughts, seeking to build in concrete measures in order to carry out the practices of the communication conglomerates. It was necessary to break with the old order and to create a new one that would enable change in both communication and practical forms (UNESCO 1988, XII-XIII).

\section{References}

Amin, Samir. 2003. 'Refundar a solidariedade dos povos do sul.' In Theotonio dos Santos, Carlos Eduardo Martins, Fernando Sá and Mónica Bruckmann (eds), Os impasses da Globalização (Series: Hegemonia e Contra-Hegemonia, Vol. 1). Rio de Janeiro: PUC-RIO.

Anderson, Perry. 1995. 'Balanço do Neoliberalismo.' In Emir Sader and Pablo Gentili (eds), Pós-neoliberalismo: as políticas sociais e o Estado democrático. Rio de Janeiro: Paz e Terra, pp. 9-23.

Arrighi, Giovanni. 2003. 'Hegemonia e movimentos anti-sistêmicos.' In Carlos Eduardo Martins, Fernando Sá and Mónica Bruckmann (eds), Os impasses da Globalização: Hegemonia e Contra-Hegemonia, Vol. 1. Rio de Janeiro: PUC-RIO.

Arrighi, Giovanni, Terence K. Hopkins and Immanuel Wallerstein. 1989. Antisystemic Movements. New York: Verso.

Batista, Paulo Nogueira. 1994. 'O Consenso de Washington: A visão neoliberal dos problemas latino-americanos.' Caderno Dívida Externa 6 (2). At http://www.consultapopular.org.br/sites/default/files/consenso\%20de\%20washington.pdf [Accessed on 20 October 2016].

Bethell, Leslie. 1999. História da América Latina. Vol. 2. São Paulo: EDUSP.

Bolaño, Cesar. 2000. Industria cultural, informação e capitalismo. São Paulo: Ed. Hucitec/Ed. polis.

Cano, Wilson. 2002. 'Venezuela: limites para uma nova política econômica.' Economia e Sociedade 11 (1): 95-127.

Carmo, Corival Alves, Pedro Silva Barros and Leonardo Valente Monteiro. 2007. Venezuela: Mudanças e perspectivas. Brasília: Fundação Alexandre de Gusmão.

Chávez, Hugo. 2007. Discurso presidencial em defesa da TeleSUR e do processo de integração regional entre os povos. 29 de agosto de 2007. At http://www.telesurtv.net/news/Chavez-simbolo-deunidad-20150727-0055.html [Accessed on 22 August 2016].

Chartrand, Harry Hillman. 2000. 'Toward an American arts industry.' In Joni M Cherbo and Margaret J Wyszomirski (eds), The Public Life of the Arts in America. Piscataway: Rutgers University Press, pp. 22-49.

Costa, Antonio Luiz M C da. n.d. 'PDVSA.' Enciclopédia Latino-Americana. At http://latinoamericana.wiki.br/verbetes/p/pdvsa [Accessed on 19 February 2017].

Fiori, José Luís. [2004] 2005. 'O poder global dos Estados Unidos: formação, expansão e limites.' In José Luís Fiori (ed), O Poder Americano. Petrópolis: Vozes.

Fontes, Pablo. 2017. Mídia e Estado: Mídia e Relações Internacionais: Criação e Existência da TeleSUR na Era Chávez (1999-2013). Master’s dissertation, Universidade Estadual do Rio de Janeiro (UERJ), Brazil.

Fontes, Pablo and Yasmin Renni. 2016. 'Integração Regional e Petróleo: Um Panorama da Política Externa dos Governos Hugo Chávez (1999-2013).' Oikos (Rio De Janeiro) 15 (2): 61-72. 
Gilboa, Eytan. 2001. 'Diplomacy in the media age. Three models of uses and effects.' Diplomacy \& Statecraft 12 (2): 1-28.

Gott, Richard. 2014. 'O Roberto Marinho da Venezuela chamava os chavistas de 'macacos.' DCM [online], 22 February. At https://www.diariodocentrodomundo.com.br/o-roberto-marinho-da-venezuela/ [Accessed on 18 February 2017].

Gramsci, Antonio. 1983. Cadernos de um Cárcere, Vol. 3. Rio de Janeiro: Civilização Brasileira. 1982. Os intelectuais e a Organização da Cultura. Rio de Janeiro: Civilização Brasileira.

Guimarães, Cesar. 2008. 'Integração Hemisférica ou Integração Autônoma' In Maria Regina Soares de Lima (ed), Desempenho de governos progressistas do Cone Sul. Rio de Janeiro: Edições Iuperj.

Hallin, Daniel and Stylianos Papathanassopoulos. 2002. 'Political clientelism and the media: Southern Europe and Latin America in comparative perspectiv.e’ Media, Culture \& Society 24 (2): 175-195. Harnecker, Marta. 2004. Taller de Alto Nivel "El nuevo mapa estratégico" 12 y 13 de Noviembre de 2004. At http://www.urru.org/papers/El_nuevo_mapa_estrategico.pdf [Accessed on 3 July 2016].

Held, David and Anthony Mcgrew. [2000] 2001. Prós e contras da globalização. Rio de Janeiro: Zahar editor.

Ianni, Octavio. 2003. Teorias da globalização. Rio de Janeiro: Civilização Brasileira.

Jesús Silva, R. 2008. ““Tres R” revolucionarias de nuestro Comandante Chávez.' Aporrea [online], 10 January. At https://www.aporrea.org/actualidad/a48979.html [Accessed on 24 June 2017].

Hobsbawm, Eric. 2014. A Era dos Extremos: O Breve Século XX (1914-1991). Rio de Janeiro: Companhia das Letras.

Kfuri, Regina and Fidel Perez Flores. 2009. 'Socialismo, Multipolaridade e integração regional na política externa do Hugo Chávez.' Paper delivered at ISA/ABRI Joint International Meeting: Diversity and Inequality in World Politics, Rio de Janeiro, Brazil 22-24 July.

Lessa, Mônica Leite. 2002. Relações culturais internacionais. In Lená Medeiros de Menezes, Denise Rollemberg and Oswaldo Munteal (eds), Olhares sobre o politico. Rio de Janeiro: EdUERJ/FAPERJ.

. 2012. 'Bens e Serviços Culturais: O Lugar do Brasil na Cena Internacional (2001-2006).' In Hugo Rogelio Suppo and Mônica Leite Lessa (eds), A quarta dimensão das relações internacionais: a dimensão cultural. Rio de Janeiro: Editora Contra Capa.

Lichtenberg, Judith. 1990. 'Foundations and limits of freedom of press.' In Judith Lichtenberg (ed), Democracy and The Mass Media. London: Cambridge University Press.

Macbride, Report. 1983. Communication and Society Today and Tomorrow: Many Voices One World: Towards a New More Just and More Efficient World Information and Communication Order. Paris: UNESCO; London: Kogan Page; New York: Unipub.

Maringoni, Gilberto. 2008. A Revolução Venezuelana. São Paulo: Editora UNESP.

Milza, Pierre. 1980. 'Culture et relations internationales.' Relations Internationales 24: 361-379.

Moraes, Denis de. 2009. A batalha da Mídia: Governos Progressistas e Políticas de Comunicação na América Latina e outros ensaios. Rio de Janeiro: Pão e Rosas.

. 2011. Vozes Abertas da América Latina: Estado, políticas públicas e democratização da comunicação. Rio de Janeiro: Mauad X.

Moraes, Gláucia da Silva Mendes. 2015. Pátria Grande À Vista: TeleSUR e as contradições da integração da América Latina. PhD thesis, Universidade Federal do Rio de Janeiro (UFRJ), Brazil. 
Pieretti, Max Römer. 2014. 'Venezuela a partir de Chávez: identidad cultural y política.' Historia y Comunicación Social 19: 55-65.

Postil, John. 2012. 'Digital politics and political engagement.' In Heather A Horst and Daniel Miller (eds), Digital Anthropology. London: BERG.

Recuero, Raquel. 2009. Redes Sociais na Internet. Porto Alegre: Editora Sulina.

Sader, Emir. 2010. A nova toupeira: os caminhos da esquerda latino-americana. São Paulo: Editora Boitempo.

2003. 'América Latina no século XXI: Perspectivas e desafios para o futuro.' Observatorio Social de América Latina 9 (1): 1515-3282.

. 2006. 'O longo ciclo eleitoral latino-americano.' Observatorio Social de América Latina VII (21): $15-22$.

Santos, Milton. [2000] 2015. Por uma outra Globalização. Rio de Janeiro: Editora Record.

Santos, Suzy dos. 2008. 'Os prazos de validade dos coronelismos: transição no coronelismo e no coronelismo eletrônico.' In Enrique Saravia, Paulo Emílio Matos Martins and Octavio Penna Pieranti (eds), Democracia e Regulação: dos meios de comunicação de massa. Rio de Janeiro: FGV.

Santos, Theotônio dos. 2000. A teoria da dependência. Balanço e perspectivas. Rio de Janeiro: Editora Civilização Brasileira.

Sarti, Ingrid. 2000. 'A construção midiática da política e a crise da representação.' Paper delivered at $24^{\text {th }}$ Annual Conference of ANPOCS, Caxambu, Brazil, 23-27 October. At http://www.anpocs.com/ index.php/encontros/papers/24-encontro-anual-da-anpocs/gt-22/gt08-18/4787-isarti-a-construcao/file [Accessed 16 October 2016].

Serpa, Marcelo. 2014. Eleições Espetaculares: Como Hugo Chávez conquistou a Venezuela. Rio de Janeiro: Editora Contra Capa.

Sodré, Muniz. 2006. As estratégias sensíveis: Afeto, mídia e política. Petrópolis: Editora Vozes.

TeleSUR. 2016. 'Satélite Simon Bolívar: 7 años impulsado el desarrollo venezolano.' TeleSUR [online], 10 January. At http://www.telesurtv.net/news/Satelite-Simon-Bolivar-7-anos-al-servicio-de-Venezuela--20160110-0011.html [Accessed on 26 June 2016].

UNESCO. 2009. Relatório da Unesco Investir na Diversidade cultural e no Diálogo Intercultural. At https://unesdoc.unesco.org/ark:/48223/pf0000184755_por [Accessed 16 October 2016].

2015. The Globalisation of Cultural Trade: A shift in Consumption - International flows of cultural goods and services 2013-2014. At https://en.unesco.org/creativity/files/globalisation-cultural-trade-shift-consumption [Accessed 16 October 2016].

Valente, Leonardo Monteiro. 2007. A Política Externa na era da Informação. Rio de Janeiro: Editora Revan.

2012. Inimigos sim, negócios à parte: revisionismo periférico e pragmatismo comercial combinados na política externa do governo de Hugo Chávez. PhD thesis, Universidade do Estado do Rio de Janeiro (UERJ), Brazil.

Asamblea Nacional [Bolivarian Republic of Venezuela]. 2005. Gaceta Oficial Número $n^{\circ} 38.281$. Caracas, 27 September. At http://www.wipo.int/edocs/lexdocs/laws/es/ve/ve042es.pdf [Accessed on 23 May 2016].

Wallerstein, Immanuel. 2001. The Essential Wallerstein. New York: The New Press. 
Williams, Raymond. [1952] 2005. Cultura e Materialismo. São Paulo: UNESP.

Ype, César, Luiz de Andrade Filho and Pedro Tiê Candido Souza. 2014 'Diplomacia Pública no Brasil.' Juca Revista [online], 10 August. At http://www.institutoriobranco.itamaraty.gov.br/images/ juca/juca_07_completa_web.pdf [Accessed on 06 September 2018].

\section{About the authors}

Pablo Victor Fontes is a Ph.D. candidate in International Relations at Insituto de Relações Internacionais da PUC-Rio (IRI/PUC-Rio). He holds a master's degree in International Relations from the Universidade Estadual do Rio de Janeiro (UERJ) (2017), a Bachelor of Journalism from the Federal University of Sergipe (UFS) (2012) and a Bachelor in Social Communication Audio-visual from the Federal University of Rio de Janeiro (UFRJ) (2011). He is Vice-Coordinator of the Laboratory of Media Studies and International Relations (LEMRI/UFRJ) and a member of Associação Brasileira de Relações Internacionais (ABRI), the Brazilian Association of Political Science (ABCP), the Latin American Studies Association (LASA) and the International Studies Association (ISA). Topics of interest include: International Security, Humanitarian Issues, Colonialism, Media, Aesthetics, Culture and International Relations.

Mônica Leite Lessa is an associate professor, in the Department of International Relations, University of the State of Rio de Janeiro (UERJ). She holds a degree in History from the Fluminense Federal University (1983) and a master's degree (1991) and doctorate in History of the Contemporary World from the University of Paris X (1997). She was a Visiting Professor at Université Paris II (2006). Her post-doctoral dissertation was in Social Sciences at the Institute of Research Gino Germani - Faculty of Social Sciences, IIGG, Argentina (2017). She coordinated the Post-Graduate Program in International Relations for the 2015-2016 biennium at the State University of Rio de Janeiro. Her main research topics are: International Politics, History of International Relations, Culture and Communication in International Relations. 


\section{Uma Política Cultural Inovadora no Panorama da Era Chávez}

Resumo: Esse artigo examina o setor audio-visual da Venezuela e suas políticas culturais e de mídia durante a Era Chávez (1999-2013). Consequentemente, essa análise enfatiza, essencialmente, como a percepção de Chávez sobre a falta de representação em relação à cultura popular venezuelana serviu de base para propor reformas políticas de cultura e mídia. Tendo em mente este cenário, ressaltamos que essa iniciativa se deu com o objetivo de resgatar, promover e valorizar a especificidade nacional e estimular a inclusão da população e o desenvolvimento social. Nesse sentido, apontamos que a reconstituição do tecido social da Venezuela se daria por meio de uma nova, importante e original agenda de bens culturais e/ou audiovisuais. Além disso, sugerimos que, até certo ponto, haveria a mesma possibilidade na América Latina.

Palavras-chave: Venezuela; cultura; mídia; Hugo Chávez; globalização.

Received on 26 February 2018, and approved for publication on 3 December 2018. 